\title{
Learning from Each Other: Respecting Cultural Differences in an InTERnational ReSEARCH Agenda ${ }^{1}$ \\ Aprendendo uns com os Outros: Respeitando DiferenÇAS CULTURAis em UMA AGENDA DE PESQUISA INTERNACIONAL
}

Richard ROSE ${ }^{2}$

\begin{abstract}
As opportunities for international research collaboration increase, it becomes increasingly important to recognise the importance of respecting cultural differences in our traditions and approaches to the research process. By discussing these differences and also establishing common ground, it is possible to strengthen research capacity and draw upon a range of methodological and philosophical expertise. Such a process should also enable educational researchers to reconsider their relationships with other professionals and to engage with them in order to ensure that effective dissemination informs policy and practice. This necessitates the promotion of wider partnerships for research that respect the professional skills of teachers and other users of educational research. This paper challenges the notion that research should be exclusively located within the academy and calls for a reappraisal of working practices, that may lead to a more collegiate approach which thereby directly influences teaching and learning.
\end{abstract}

KEYWORDS: Special Education. Intercultural Research. International Research.

RESUMO: como oportunidades de colaboração de pesquisa internacional aumentaram, tornou-se importante reconhecer a relevância do respeito às diferenças culturais de nossas tradiçóes e às abordagens para o processo de pesquisa. Discutindo essas diferenças e também estabelecendo um campo comum, é possível fortalecer a capacidade de pesquisar e basear-se em uma variedade de expertise metodológica e filosófica. Tal processo deve também permitir que pesquisadores da educação reconsiderem suas relações com outros profissionais e, conjuntamente, comprometam-se a assegurar que a disseminação subsidie políticas e práticas. Isso requer a promoção de parcerias mais amplas para pesquisa, que respeitem as habilidades profissionais de professores e outros usuários da pesquisa educacional. Este artigo desafia a noção de que a pesquisa deve estar exclusivamente localizada dentro da academia e clama por uma reavaliaçáo das práticas de trabalho que possam levar a uma abordagem corporativa que, diretamente, influencie o ensino e a aprendizagem.

PALAVRAS-CHAVE: Educação Especial. Pesquisa Intercultural. Pesquisa Internacional.

\section{REASSERTING THE PURPOSE OF EDUCATIONAL RESEARCH}

A few years ago the Australian educational researcher Lyn Yates wrote a book with the challenging title What Does Good Education Research Look Like? (YATES, 2004). Titles such as this are clearly intended to be provocative. The contents of the text are aimed at both established and early career researchers, with chapters focused upon the commissioning of research, the role of journals in dissemination and the quality of doctoral research studies. In her introduction to the book, Yates emphasises that questioning the quality of research is not simply a matter for academics, and that increasingly those individuals and groups that might be described as the end users of educational research are also asking the question: what constitutes good research? Yates makes a good case for both re-examining the nature and purpose of research and for a discussion about who needs to be involved at each stage of the research process. In this paper, I will endeavour to examine aspects of this question and to suggest that the time is right for a reappraisal of our role as researchers and the ways in which we conduct and disseminate our work.

\footnotetext{
${ }^{1}$ http://dx.doi.org/10.1590/S1413-65382216000200002

${ }^{2}$ Director of the Centre for Education and Research, University of Northampton, UK. Richard.Rose@northampton.ac.uk
} 
Yates is not the first person to ask critical questions about the nature and purpose of research in education. More than thirty years ago, Lawrence Stenhouse was questioning the value and efficacy of much of the research being conducted into various aspects of education at that time (STENHOUSE, 1981, 1983). Stenhouse held a number of influential positions within UK and international research organisations and was often seen as someone who challenged the existing hegemony within educational research communities. In particular, he asserted the necessity of blurring the lines between teaching and researching, suggesting that these two educational components should nourish each other through a common purpose of generating knowledge that was of value to those engaged in a common mission. In common with more recent researchers in this field (EDWARDS; SEBBA; RICKSON, 2007; JAMES, 2011), he called upon those involved in educational inquiry to engage in conversations with policy makers, teachers, parents and children in order to ensure that the value of educational research could be assured and acknowledged. Several writers on educational research have asserted that teachers are in many ways natural researchers, continuously asking questions about the students they teach, the curriculum they are required to deliver and the efficacy of teaching approaches (BABKIE; PROVOST, 2004; KINCHELOE, 2012). This being the case, I would suggest that the kinds of partnerships that we build with other colleagues in education may be an important factor in determining the value and quality of our work as researchers.

Stenhouse often referred to teachers as artists, using their creativity to both generate and disseminate knowledge, and opposed those who wished to identify research in staid, traditional and semi-positivistic ways.

All good art is an inquiry and an experiment. It is by virtue of being an artist that the teacher is a researcher. The point appears to be difficult to grasp, because education faculties have been invaded by the idea that research is scientific and concerned with general laws. This notion persists even though our universities teach music and literature and history and art, and lay an obligation on their staff in these fields to conduct research. Why then should research in education look only to science? (STENHOUSE, 1988, p.47).

For Stenhouse, the necessity to see research as a creative process also meant that we should recognise that it is not solely the domain of the academic researcher, but rather a process that introduces rigour and a systematic approach to our understanding of teaching and learning through the establishment of professional partnerships. One aspect of respecting cultural difference may well be dependent upon our ability to see the different cultures in which academic researchers and school based professionals exist, even within a single country. Closing the gap between these would have benefits for all parties.

\section{RECOGNISING RESEARCH TRADITIONS AND RESPECTING NATIONAL DIFFERENCES}

Conducting respectful research should be at the core of everything that we do. This means that we must recognise that when working across cultures, in different linguistic traditions or with colleagues whose backgrounds differ from our own, we need to make an effort to appreciate their context and those influences that shape their interpretation of the world.

Educational research has evolved in a variety of ways in different countries. Within the UK the disciplines of psychology, philosophy and sociology and to a lesser extent history have 
all had an influence upon the way research has been shaped and conducted (MCCULLOCH, 2002; LAWN; FURLONG, 2007). Whilst it has been argued that this influence has to an extent decreased in recent years (BRIDGES, 2006), the framework upon which much reported educational research has been constructed still bears the hallmark of these four pillars. There has undoubtedly been some advantages gained from working within this structure, but there have also been concerns expressed that as an area of inquiry with its own unique features, and which does not necessarily sit easily within these disciplines, educational research may need to develop its own methods and approaches (GEE 2001; FENWICK; EDWARDS; SAWCHUCK, 2011).

Because of the traditions associated with research related in particular to psychology and sociology, educational researchers have often attempted to embrace methodologies that are not wholly suited to educational contexts. In particular, the dominance of positivistic methods that informed much of the research activity of the early half of the twentieth century has been viewed as too clinical and removed from the human elements required for understanding the relationships that often influence teaching and learning in educational environments. Because of this, a greater emphasis upon interpretivist approaches has become the norm in much of the educational research undertaken. The move towards methodologies drawing upon phenomenology, grounded theory and naturalistic inquiry has been embraced by many educational researchers and has been encouraged by those working within emancipatory or feminist research and others who are committed to involving the subjects of research as partners in the investigative process. In much of the educational research reported from western Europe and North America in recent years there has been an emphasis upon interpretative approaches, with a clear intention that educational researchers should express their own identity. However, it is important to recognise that this move has not been met with universal approval, neither is it the dominant approach in all educational research cultures (WATSON, 1999).

Critics of interpretative inquiry question the ability of researchers to demonstrate the trustworthiness of findings (GOERING; STREINER, 1996). This lack of confidence can be seen in many countries where research continues to be seen as providing the means to measure phenomena and to implement statistical procedures in order to ensure reliability and validity. Atkinson and Delamont (2006) challenged the notion that researchers should be restricted in their approach by a slavish adherence to these semi-positivistic, pseudo-scientific methods and paradigms. This issue is expanded upon by Denzin (2009) who urges researchers to adopt flexible approaches that are not driven by quantitative criteria, which can at times remove the important human element from the work that we are undertaking. In common with other researchers (HAMMERSLEY, 2005; ONWUEGBUZIE; LEECH, 2006), Denzin believes that qualitative research has been unfairly criticised because of the misconstrued suggestion that quantitative researchers work within a more definitive framework, and that this finds more favour with policy makers. An obsession with a simplistic model of research based upon randomised control trials has, in Hammersley's view resulted in a distorted view of the purpose of educational research and the necessity to make it accessible to a wider education community. Gersten, Baker and Lloyd (2000) suggest that the main problem with quantitative approaches based upon experimental design is that efforts to control and manipulate narrow and precisely defined independent variables fail to produce a detailed understanding of classroom based phenomena, and therefore this is of little use to most end users of research. 
Biestra (2011) emphasises the differences of approach to both the study of education and research in this field that exist across nationalities and cultures. Specifically, he emphasises how in much of Europe, and specifically in the German speaking world, education has been regarded as a discipline in its own right and on a par with those that have traditionally influenced UK and USA researchers. This, he suggests has enabled educational researchers in these wider European communities to generate their own theory, rather than drawing these from largely sociological or psychological approaches, thereby generating greater respect for education as an academic discipline and the basis for legitimate research. Researchers who come from a pedagogical background need to have the confidence to express their work and conduct their investigations in a manner best suited to education as a discipline, and to challenge outmoded notions that a quasi-experimental approach is the only one that can be justified.

\section{BUILDING NETWORKS}

Reconciling differing perspectives of the nature and purpose of educational research often presents a challenge when building networks within an international arena. Time spent at the outset discussing differences and identifying personal strengths and interests can often be invaluable when beginning international projects. I personally recall working on a project with colleagues in Estonia whose approach to research was strongly influenced by a positivist model and whose perception of data was couched in wholly quantitative terms. The discussions which we had about the relative merits of qualitative interview and observation data, as opposed to the statistical analysis of large questionnaire data sets were at the outset difficult. However, we soon recognised that by employing a mixed methods approach we could play to everyone's strength and generate a range of data to address the research questions at the heart of the project.

As someone whose research has been mainly directed towards issues of special educational needs and inclusion, I am conscious that in some societies, earlier models of defectology still persist. An examination of journals from, for example, former soviet states, provides evidence that positivist methods and quasi-scientific approaches to data collection and analysis still dominate. For example, the Baltic Journal of Special Education, a well respected peer reviewed journal that is registered with several of the leading index organisations still refers in its advice to authors to a focus on scientific discussion, and refers to issues of special educational needs as scientific problems. Such language may appear alien to those of us working in more interpretive traditions, but remains a reality for a significant number of educational researchers. Our choices would appear to be to ignore these colleagues, challenge their ways of working, or to engage them in discussion in order to see what we can learn from each other. Personally, I would prefer to see us embrace the latter option.

Entering into a research partnership requires that all members of a team identify the strengths and skills of their colleagues. Indeed, when this happens it can be seen as an effective way to learn new approaches to research that might otherwise have been overlooked. Equally important are the partnerships that we establish with other agencies involved in the process, whether these be teachers, parents, students or other professionals (SCHUCK, 2012).

Whilst it is now generally recognised that diverse paradigms and methodological approaches have come to characterise research in different countries, less attention has been given 
to the thorny, and often contrived matter of theoretical or philosophical models. In much of the English speaking world educational researchers have been pleased to align themselves with theoretical frameworks borrowed from philosophy or sociology. Variously describing themselves as social constructivists, post-modernists, post-structuralists or any one of a number of other umbrella titles, they have drawn on the work of a range of "theorists" upon which to hang their studies. At times the theories of Habermas, Bronfenbrenner, Foucault, Bourdieu or any of a number of others, have provided a scaffold upon which educational researchers have built their investigations. Whilst in recent years theoretical models such as that advocated in the "capability approach" (SEN, 1999; NUSSBAUM, 2011) have come into fashion, others have fallen out of favour. As Norwich (2013) has suggested whichever theoretical perspective is adopted, it is easy to find flaws in its application, particularly when applied in a context that may be at a distance from its original intent.

The discussion of theory is, of course, an important aspect of research, though it does seem that much of the work undertaken under the cover of various theories provide little insight into these in their own right. Whilst these discussions may indeed be useful, they remain limited even when educational researchers work across cultures. It is understandable that having trained and worked within a European tradition most educational researchers in my own country when discussing theory will refer to the usual suspects. However, when researching with colleagues whose frameworks may well have been more influenced by the philosophical ideas of Ashoka, Vivekananda, Mencius or Anton Wilhelm Amo, we tend to be at a loss with regards to what these eminent, but non-European theorists have to offer.

If networks are to be built across borders, I would suggest that this should be managed in a far more respectful and less imperialist manner than has typified educational research to date. Before embarking upon work of this nature I would hope that we could not only accept the methodological and paradigm differences that influence our ways or working, but also make some effort to understand the underlying philosophies that have shaped our different cultures.

\section{DisSEMINATION - MORE THAN AN ACADEMIC PROCESS}

At the outset of this short paper I suggested that I wished to re-examining the nature and purpose of educational research and also to consider the ways in which we conduct and disseminate our work. Thus far I have endeavoured to raise questions about the research process. I wish now to turn my attention to the matter of purpose and dissemination, two aspects of being a researcher that are, I believe, closely linked.

I suspect that like many working in this area, I came to educational research through a passion for teaching and understanding how this impacted upon, or in some instances failed to address the needs of learners. I like to think of educational research as being an honourable activity motivated by a desire to improve the lives of learners and teachers through structured inquiry. If educational research has a purpose, and there are those who at various times have questioned this (TOOLEY; DERBY, 1998; HILLAGE et al., 1998), it must be to ensure that education becomes more effective, equitable and accessible. If we are to judge the quality of research, we must do so in part at least, with a focus upon impact, and those best placed to make judgements about this impact may well be those who initially inspired many of us to embark upon this journey. 
At present the quality of our work as researchers is for the most part assessed by our peers. Those who assess the quality of proposals for funding to various research councils, or who make decisions over the publication of papers, are traditionally other researchers. In many ways this process works well. If someone is to pass judgement on the quality of my research design, I want to feel confident that they themselves have been involved in the research process. It is only right that at the outset, decisions about funding and the suitability of research proposals should be made by someone fully engaged in this process.

I do, however, have many concerns with regards to the final stages of research. If we are so committed as researchers to the improvement of education, why is it that we spend most of our time speaking only to other academics? Much of the concentrated effort around research dissemination involves academics presenting papers at conferences to - other researchers. Existing systems for assessing the quality of research outputs demands that we publish our work in peer reviewed academic journals, and if these happen to have a high impact factor, then this is even more desirable. However, academic journals have a readership almost exclusively comprised of other academics or students undertaking studies leading to qualifications aimed at turning them also into ersatz academics.

I am not suggesting that these behaviours should cease, though I often find myself questioning the value of conferences in terms of the dissemination of research. A twenty minute slot to discuss the findings of a two year research project must surely be one of the most artificial contrivances we have conceived to date. I am certainly in favour of work being published in rigorously managed high quality journals, but I do believe that we are also under a moral obligation to make our work accessible to those very individuals for whom we claim to undertake this work in the first place.

It is a sad reflection upon our profession that there are colleagues who see themselves as eminent researchers, but who fail to see that they have a responsibility that goes beyond the academic community. Having published papers in high ranking journals and presented at an international conference, they fail to acknowledge that the very individuals who they suggest the research is intended to benefit, have a right to access the outcomes of their labours. These elite researchers are anxious that to be seen to disseminate their work through a professional magazine or newspaper, may result in their research being belittled. Yet we know that few of the professionals, parents or indeed children who we often claim to be the potential beneficiaries of our work have any inclination to seek it out through those channels that have become the domain of the academic researcher.

If educational research is to play a significant role in the future, it is essential that those of us who are committed to this process embrace all means at our disposal to communicate with a wider audience. If we fail to recognise that social media and digital information have become the dominant means of communication, we are destined to become academic dinosaurs and face ultimate extinction. I say this as someone who continues to favour reading a paper book over a screen, and who has yet to engage with Twitter or many other of the digital platforms through which individuals exchange information. But as an academic who is committed to research as a democratic process, I believe that we have a responsibility to communicate with a wide audience using the language and methods with which they feel most comfortable. 


\section{Conclusions}

Educational research is an essential function of knowledge generation and a primary means by which we can make sense of the world. It must also be a democratic and nonexclusive process whereby we engage with people working towards a more equitable society. The opportunities to work internationally are greater now than at any time in history, and we should embrace the chance to work together and to share our ideas and knowledge. However, in order to do this effectively, we must open our minds to new ways of working, recognise that our own national approaches may have limitations and be prepared to listen to others whose interpretation of the world may be different from ours, and whose working practices may appear challenging.

Good research is respectful of those for whom we claim to embark upon our investigations. This means that we must make renewed efforts to engage in our activity with wider audiences and to make our work accessible to all who may have an interest in what we do. Educational research without teachers, learners or schools would be impossible. Therefore let us recognise that these are not simply the subject of our investigations, but ensure that they are partners in the research process at every stage.

\section{REFERENCES}

ATKINSON, P.; DELAMONT, S. 'In the Roiling Smoke: Qualitative Inquiry and Contested Fields'. International Journal of Qualitative Studies in Education, v.19, n.6, p.747-755, 2006.

BABKIE, A.M; PROVOST, M.C. Teachers as researchers. Intervention in school and clinic, v.39, n.5, p.260-268, 2004.

BIESTA, G. Disciplines and theory in the academic study of education: a comparative analysis of the Anglo-American and Continental construction of the field. Pedagogy, Culture and Society, v.19, n.2, p.175-192, 2011.

BRIDGES, D. The disciplines and discipline of educational research. Journal of Philosophy of Education, v.40, p.259-272, 2006.

DENZIN, N. The elephant in the living room: or extending the conversation about the politics of evidence. Qualitative Research, v.9, n.2, p.139-160, 2009.

EDWARDS, A.; SEBBA, J.; RICKINSON, M. Working with users: some implications for educational research. British Educational Research Journal, v.33, n.5, p.647-661, 2007.

FENWICK, T.; EDWARDS, R; SAWCHUCK, P. Emerging Approaches to Educational Research. New York: Routledge, 2011.

GEE, J.P. Identity as an Analytic Lens for Research in Education. Review of Research in Education, v.25, p.99-125, 2001.

GERSTEN, R.; BAKER, S; LLOYD, J.W. Designing high quality research in special education: Group experimental design. The Journal of Special Education, v.34, n.1, p.2-18, 2000.

GOERING, P.N.; STREINER, D.L. Reconcilable differences: the marriage of qualitative and quantitative methods. Canadian Journal of Psychiatry, v.41, p.491-497, 1996.

HAMMERSLEY, M. 'Close Encounters of a Political Kind: The Threat from the Evidence-Based Policy-Making and practice Movement', Qualitative Researcher, v.1, p.2-4, 2005. 
ROSE, R.

HILLAGE, J. et al. Excellence in Research in Schools. London: Department for Education and Employment, 1998.

JAMES, M. Growing confidence in educational research: threats and opportunities. British Educational Research Journal, v.38, n.2, p.181-201, 2011.

KINCHELOE, J.L. Teachers as Researchers: Qualitative Inquiry as a Path to Empowerment. London: Routledge, 2012.

LAWN, M.; FURLONG, J. The social organisation of education research in England. European Educational Research Journal, v.61, p.55-70, 2007.

MCCULLOCH, G. Disciplines contributing to education? Educational studies and the disciplines. British Journal of Educational Studies, v.50, n.1, p.100-110, 2002.

NORWICH, B. How does the capability approach address current issues in the special educational needs, disability and inclusive education field? Journal of Research in Special Educational Needs, v.14, n.1, p.16-21, 2013.

NUSSBAUM, M. Creating Capabilities: The Human Development Approach. London: Harvard University Press, 2011.

ONWUEGBUZIE, A.J.; LEECH, N.L. Validity and Qualitative Research: An Oxymoron? Quality and Quantity: International Journal of Methodology, v.41, n.2, p.233-249, 2006.

SCHUCK, S. The opportunities and challenges of research partnerships in teacher education. Australian Educational Researcher, v.40, n.1, p.47-60, 2012.

SEN, A. Commodities and Capabilities. Oxford: Oxford University Press, 1999.

SHENTON, A.K. Strategies for ensuring trustworthiness in qualitative research projects. Education for Information, v.22, p.63-75, 2004.

STENHOUSE, L. What counts as research? British Journal of Educational Studies, v.29, n.2, p.103$114,1981$.

STENHOUSE, L. "Research is systematic inquiry made public". British Educational Research Journal, v.9, n.1, p.11-20, 1983.

STENHOUSE, L. Artistry and teaching: The teacher as focus of research and development. Journal of Curriculum and Supervision, v.4, n.1, p.43- 51, 1988.

TOOLEY, J.; DERBY, D. Educational Research: A Critique. A Survey of Published Educational Research. London: Office for Standards in Education, 1998.

WATSON, K. Comparative Educational Research: the need for reconceptualisation and fresh insights, Compare: A Journal of Comparative and International Education, v.29, n.3, p.233-248, 1999.

YATES, L. What Does Good Education Research Look Like? Maidenhead: Open University Press, 2004.

Recebido em: 18/12/2015

Aprovado em: 04/04/2016 